\title{
若年層にみられる重度歯周炎の病理病態解析
}

\author{
II. 未梢血好中球および単球遊走能の検討 \\ 島内英俊恵比須繁之 小川知彦*岡田宏 \\ 大阪大学歯学部口腔治療学講座 \\ (主任：岡田 宏教授) \\ *大阪大学歯学部口腔細菌学講座 \\ （主任 : 小谷尚三教授） \\ (昭和 60 年 12 月 20 日受付)
}

\section{Neutrophil and Monocyte Chemotactic Response in Young Adults with Severe Periodontitis}

\author{
Hidetoshi SHIMAUCHI, Shigeyuki EBISU, Tomohiko OGAWA* and Hiroshi OKADA \\ Department of Periodontology and Endodontology, Osaka University, Faculty of Dentistry \\ (Chief : Prof. Hiroshi OKADA) \\ *Department of Microbiology and Oral Microbiology, Osaka University, Faculty of Dentistry
}

(Chief : Prof. Shozo KOTANI)

\begin{abstract}
Neutrophil and monocyte chemotactic response were evaluated in eight patients with severe periodontitis, aged in the range from 18 to 26 years. On the basis of clinical and radiographic measurements, four patients were classified generalized type, and four were localized type. The chemotactic response was measured by a membrane filter method using a multiwell chemotaxis assembly, and patient's peripheral neutrophils or monocytes were compared with those of control healthy subjects, using $N$-formyl-Lmethionyl-L-leucyl-L-phenylalanine and endotoxin activated human serum as the standard chemoattractants.
\end{abstract}

Based upon statistical analysis of chemotaxis assays, neutrophil chemotactic response was significantly elevated in one of four generalized type patients. In four localized type patients, one patient showed elevated neutrophil chemotactic response, and two patients exhibited depressed chemotactic response.

In four generalized type patients, one patient exhibited depressed monocyte chemotactic response, and elevated monocyte chemotactic response was found in one patient. In four localized type patients, two patients showed depressed monocyte chemotaxis, and these patients had neutrophil defect together.

The effect of periodontal treatment on neutrophil and monocyte chemotaxis was studied in two localized type patients. In these patients, depressed neutrophil and monocyte chemotaxis were observed before and after periodontal therapy.

Key words : Juvenile periodontitis, Chemotactic response, Neutrophil, Monocyte

要旨 : 18 26 歳の重度歯周炎患者 8 名 (広汎型 4 例, 限局型 4 例) の末梢血好中球および単球の遊走能を検索した。 
その結果, 好中球遊走能は, 歯周組織に異常を認めない健常者に比べて, 広沉型 4 例中 1 例に有意の六進, 限局型では 4 例中 1 例に有意の六進， 2 例に有意の低下が認められた。また，単球遊走能は，広沉型 4 例中 1 例に有意の亢進， 1 例に有意の低下が認められたのに対し，限局型では 4 例中 2 例に有意の低下が認められた。この単球遊走能の低下を示 した限局型患者 2 名は，好中球の遊走能もやはり低下していた。さらに，好中球と単球の遊走能の低下が治療前に存在 した 2 例について, 歯周治療終了後に再度検索を行った結果, やはり依然として好中球と単球の遊走能の両方に遊走能 の低下が認められ, これらの患者における遊走能の低下は, 患者の生来保有している素質であることが示唆された。

索引用語 : 若年性歯周炎, 遊走能, 好中球, 単球

\section{緒言}

歯肉の接合上皮や結合組織，さらには歯肉溝あるいは 歯周ポケットへの好中球 (多形核白血球) の集積は，慢 性歯周疾患の特徴的な組織像である1)。血液循環から離 れると, 好中球や単球一マクロファージ系細胞は局所に 遊走し, 細菌など異物を取り込み, それらを殺してしま う。こうした好中球の血管より歯肉溝への遊走が, 歯周 組織におけるプラーク細菌に対する生体防御の一つであ ることが知られている ${ }^{2 \sim 4)}$ 。た，ヒトのプラーク中に 好中球に対する走化性因子が含まれていることも報告さ れている5,6)。このように，好中球あるいは単球一マク口 ファージ系細胞は, 歯周組織における生体防御機構の中 で重要な役割を果たしていると考えられている。

好中球に機能障害のある患者, 例えば Chédiak-

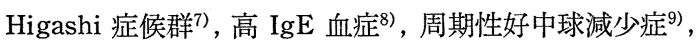
白血球機能不全症候群 ${ }^{10)}$ そして糖 尿病患者 ${ }^{11,12)}$ などで は，激烈な炎症を伴なった歯周組織破壊が報告されてお り, 好中球の機能低下が, 細菌感染に対する防御機構の 低下を引き起こすことにより，急激な歯周組織破壊の一 因となっていることが示唆されている。

最近, 限局型若年性歯周炎 (Localized Juvenile Periodontitis, 以下 LJP と略す) 患者の多くに好中球の遊 走能の低下が認められることが報告され $\left.{ }^{13} 17\right)$, この遊走 能の低下と LJP の発症との関連性が注目されている。 さらに, 広汎型若年性歯周炎 (Generalized Juvenile Periodontitis, 以下 GJP と略す) においても, 患者の 約半数に好中球の遊走能低下が報告されている ${ }^{16 ~ 18) 。 ま ~}$ た, 比較的若い成人層に認められる広沉型の重度歯周炎 である Rapidly progressive periodontitis 患者でも，好 中球あるいは単球遊走能の低下が報告されている ${ }^{19)}$ 。し かしながら，我国における若年性歯周炎患者の好中球あ るいは単球の遊走能についてはほとんど検索がなされて おらず，その実態は明らかではない。

本教室では, 我国における若年層の重度歯周炎の病態
を明らかにする目的で, 大阪大学歯学部附属病院歯周病 診療室を受診した初診時年齢 18〜26 歳の重度歯周 炎 患 者 8 名の病態を検討し, その臨床所見, 血液所見, 免疫 病理学的検討結果について前論文 ${ }^{20)}$ で報告した。本論文 では, にれら 8 名を対象として, 未梢血の好中球と単球 の遊走能を測定した結果について報告する。

\section{材料および方法}

\section{1. 被 検 者}

本研究の被検者は, 大阪大学歯学部附属病院歯周病診 療室を受診した患者 8 名で, 初診時年齢 18〜26 歳 (平均 年齢 22.6 歳), 男性 3 名, 女性 5 名である。これら 8 名 の臨床所見, 血液検査の結果抢よび免疫病理学的検索結 果に関しては前論文 ${ }^{200}$ に記した。本研究の対象である 8 症例は, その臨床所見により, 広汎型 4 例（症例 1 4） および限局型 4 例（症例 5 8）に分類された ${ }^{20) 。 ~}$

各症例の患者の正中皮静脈より歯周治療開始前に各々 $10 \mathrm{~m} l$ 採血を行い, 一方, 全身的疾患が無く歯周組織に 特に異常を認めない被検者を選択し, 健常者として同様 に採血した。両者について同時に好中球および単球の分 離を行い, それらの遊走能を測定して比較検討した。

\section{2. 患者末梢血好中球および単球の遊走能の検定}

1）好中球および単球の分離

ヘパリンナトリウム注射液 (小玉 K.K., 東京) を容れ たプラスチック注射器を用いて, 患者扮よび健常者の正 中皮静脈より静脈血を採血し(ヘパリン濃度は血液 $1 \mathrm{~m} l$ 当り 20 単位), Boyüm の方法 ${ }^{21)}$ に従い, 単核細胞浮遊液 を調整した。すなわち, ヘパリン液の 1 容にリン酸緩衝 生理食塩水 (PBS, pH 7.0) の 3 容を加えて希釈したも のを, Ficoll-Paque 液 (Pharmacia Fine Chemicals, Uppsala, Sweden) 上に重層した後, 室温で $400 \times g, 35$ 分間遠心した。単球に富む画分を採取し, PBS で洗浄後, $2 \%$ ウシ血清アルブミン (Sigma Chemical Co., St. Louis, MO, USA) と $20 \mathrm{mM} \mathrm{N-2-ハイドロキシエチル}$ ピプラジン- $N^{\prime}-2-$ エタンスルフォン酸 (HEPES) (Sig- 
ma) を含む Gey’s 均衡塩類溶液 (Gibco Laboratories, Grand israd, N.Y., USA) ${ }^{22)}$ (Gey's BSA, pH 7.0) に, この単球に富む画分を細胞濃度 $5 \times 10^{6}$ 個 $/ \mathrm{m} l$ になるよ らに浮遊させた。

次に, 単球に富む画分を採取した後に残った沈査を, 赤血球溶解液 (蒸溜水 $1 l$ 中に $\mathrm{NH}_{4} \mathrm{Cl} 8.29 \mathrm{~g}, \mathrm{KHCO}_{3} 1$ $\mathrm{g}$, disodium EDTA $0.372 \mathrm{~g}$ を含む, $\mathrm{pH}$ 7.4) で処理し, PBS で 3 回洗浄し，好中球に富む画分を得た。にの画分 の細胞濃度を $2.5 \times 10^{6}$ 個 $/ \mathrm{m} l$ になるように, Gey's BSA （pH 7.2）に浮遊, 調整した。なお，この各浮遊液中の 細胞の占める割合は, 単球では約 $15 \sim 20 \%$, 好中球では $80 \%$ 以上であり，またトリパンブルー排除テストにより， 両細胞共に全細胞の $95 \%$ が生細胞であることを確 認し た。

2）標準走化性因子

本研究で用いた標準走化性因子は，N-フォルミル-Lメチオニル-L-ロイシル-L-フェニルアラニン (FMLP) 23) (Sigma) と LPS 活性化ヒト血清24)である。FMLP は $10^{-2} \mathrm{M}$ の濃度にエタノールに溶解したものを $-20^{\circ} \mathrm{C} て ゙$ 保存した。また LPS 活性化ヒト血清は, 新鮮ヒト血清 $1 \mathrm{~m} l$ に, 生理食塩水に $0.2 \mathrm{mg} / \mathrm{m} l$ の割合に溶解した Escherichia coli (Serotype 055 : B 5) (Sigma) 由来の LPS $0.1 \mathrm{~m} l$ を加えて, $37^{\circ} \mathrm{C}$ で 60 分間反応させた後, $20,000 \times g, 4^{\circ} \mathrm{C}, 15$ 分間遠心することにより上清として 得た。この LPS 活性化ヒト血清は $56^{\circ} \mathrm{C}, 30$ 分間加熱し て非働化した後, $-20^{\circ} \mathrm{C}$ に保存した。いずれの走化性 因子も使用直前に解凍し, Gey's BSA 7 容とゼラチン 加ヴェロナール緩衝液 5 容とを混合した培養液 (Gey's

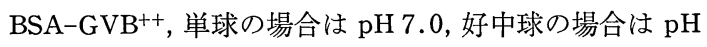
7.2)により所定濃度に稀釈して用いた。すなわち, 遊走 能の検定における陽性対照として, 単球では $10^{-8} \mathrm{M}$ 濃 度の FMLP, 10 倍稀釈の LPS 活性化ヒト血清を用い, 好中球では $10^{-6} \mathrm{M}$ 濃度の FMLP, 2 倍稀釈の LPS 活 性ヒト血清を用いた。

3）遊走能の検定

48 穴走化チェンバー (Neuro Probe, Cabin John, Md, USA）を用いて実施した ${ }^{25,26) 。 す な わ ち, ~ G e y ’ s ~ B S A-~}$ $\mathrm{GVB}^{++}$に溶解した標準走化性因子あるいは対照培養 液 をチェンバーの bottom plate の凹み (下室) に満たし， 次いで厚さ約 $10 \mu \mathrm{m}$ のポリカーボネートメンブレンフ イルター（Neuro Probe）およびシリコン製ガスケット を装着した。なお, メンブレンフィルターは, 単球遊走 能の検索を行う場合には孔径 $5 \mu \mathrm{m}$ のものを, 好中球に は孔径 $3 \mu \mathrm{m}$ のものを用いた。次いで, top plate を取
り付け, 各凹み（上室）に患者あるいは健常者の細胞浮 遊液 $50 \mu l$ ずつを加えた。そして, $5 \% \mathrm{CO}_{2}-95 \%$ 空気の 気相下で, 単球の場合には 90 分間, 好中球の場合には 60 分間, $37^{\circ} \mathrm{C}$ で各々培養した。培養終了後, メンブレ ンフィルターを取りはずし, Falk らの方法 ${ }^{25)}$ に従って, Diff-Quick（国際試薬 K.K., 神戸）の固定液, 染色液 I 液, II 液の順にメンブレンフィルターを各 30 秒間浸し て, 細胞の固定, 染色を行った。そして, このメンブレ ンフィルターをスライドガラス上で風乾した後, immersion oil (日本化学工業 K.K., 東京) を滴下し, カバーガ ラスをかけて封入した。

遊走細胞数の算定は, 下室に接していたフィルター面 を 100 倍の対物レンズと 10 倍の接眼レンズを装着した 光学顕微鏡にて検鏡し, 接眼レンズに取り付けた $5 \mathrm{~mm}$ $\times 5 \mathrm{~mm}$ の正方形グリッド内にみられる遊走細胞数を, 無作為に 20 グリッド数えることにより行った。すなわ ち,フィルター下面まで遊走した単球あるいは好中球の 一視野当たりの平均数 (数えた細胞の総計 $\times 0.6[$ 一視野 は 12 グリッドに相当する〕）を, 患者抢よび健常者の標 準走化性因子を添加した培養と無添加の対照培養につい て各々算出した。この検定は各培養ごとに 3 通り行い, 平均值と標準誤差 (S.E.) を求めた。得られた平均值の, 健常者の無添加の培養で得られた平均值に対する比を算 出し, 刺激指数 (Stimulation index) とした。患者と健 常者の比較は, 同一の標準走化性因子に対して得られた 刺激指数を統計学的に処理し，比較することにより行っ た。

\section{結果}

末梢血好中球の遊走能の検索結果を表 1 亿示した。標 準走化性因子 (FMLP および LPS 活性化ヒト血清) の いずれかに対して, 症例 2 および 5 では遊走能の有意の 六進が認められ, 症例 7 および 8 では有意の低下が認め られた $(\mathrm{p}<0.05$, Student's $\mathrm{t}$ 検定)。病型別に分類す ると, 広汎型 (症例 1 4) 4 例中 1 例（症例 2) に遊走能 の亢進が認められ，限局型（症例 5 8) では， 4 例中 1 例に遊走能の充進 (症例 5), 2 例 (症例 7,8) に遊走能の 低下がそれぞれ認められた。

次に, 末梢血単球の遊走能の測定結果を表 2 に示し た。すなわち, 標準走化性因子のいずれかに対して, 遊 走能の有意の充進が症例 2 で認められ, 有意の低下が症 例 1,7 および 8 で認められた $(\mathrm{p}<0.05)$ 。病型別では， 健常者に比べて, 広沉型 4 例中遊走能の有意の克進（症 
表 1 末梢血好中球の遊走能

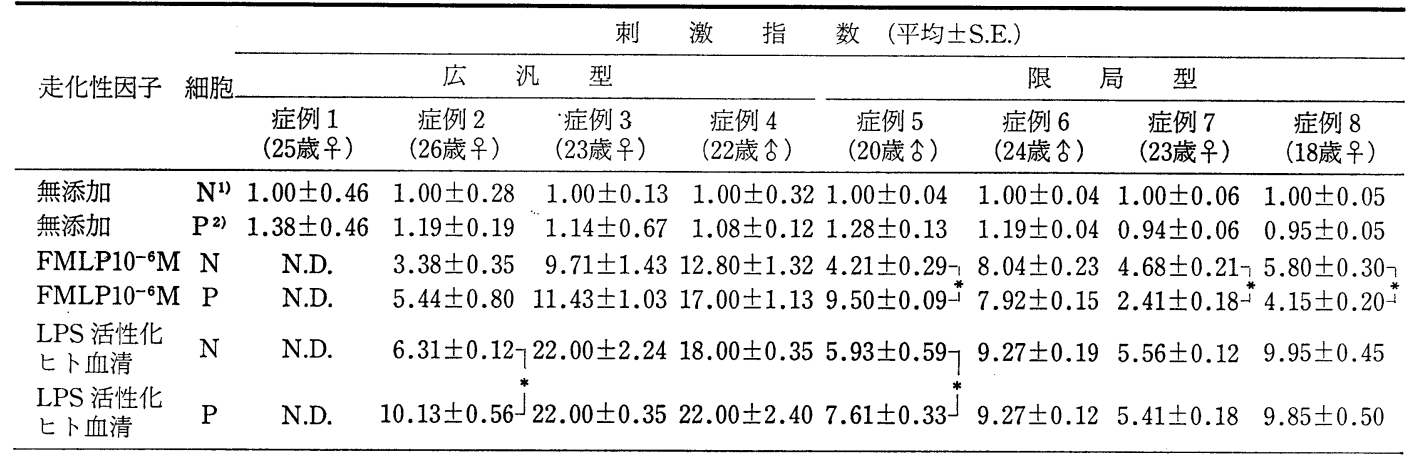

†患者および健常者の, 同じ走化性因子に対する刺激指数の間に $\mathrm{P}<0.05$ (Student's $\mathrm{t}$ 検定)で有意差のあるもの

1） N : 健常者末梢血より分離した好中球

2） P：患者末梢血より分離した好中球

表 2 末梢血単球の走遊能

\begin{tabular}{|c|c|c|c|c|c|c|c|c|c|}
\hline \multirow{3}{*}{ 走化性因子 } & \multirow{3}{*}{ 細胞 } & \multicolumn{3}{|r|}{ 刺 } & \multirow[t]{2}{*}{ 激 } & \multicolumn{4}{|c|}{ (平均土S.E.) } \\
\hline & & \multicolumn{3}{|c|}{ 広 汎 型 } & & \multicolumn{4}{|c|}{ 限 局 型 } \\
\hline & & $\begin{array}{c}\text { 症例 } 1 \\
\text { (25歳早) }\end{array}$ & $\begin{array}{c}\text { 症例 } 2 \\
\text { (26歳早) }\end{array}$ & $\begin{array}{c}\text { 症例 } 3 \\
\text { (23歳早) }\end{array}$ & $\begin{array}{l}\text { 症例 } 4 \\
\text { (22歳令) }\end{array}$ & $\begin{array}{c}\text { 症例 } 5 \\
(20 \text { 歳令 })\end{array}$ & $\begin{array}{l}\text { 症例 } 6 \\
(24 \text { 歳令) }\end{array}$ & $\begin{array}{l}\text { 症例 } 7 \\
\text { (23歳早) }\end{array}$ & $\begin{array}{l}\text { 症例 } 8 \\
\text { (18歳早) }\end{array}$ \\
\hline 無添加 & $\mathrm{N}^{1)}$ & $1.00 \pm 0.08$ & $1.00 \pm 0.10$ & $1.00 \pm 0.15$ & $1.00 \pm 0.14$ & $1.00 \pm 0.16$ & $1.00 \pm 0.00$ & $1.00 \pm 0.07$ & $1.00 \pm 0.00$ \\
\hline 無添加 & $\mathrm{P}^{2)}$ & $0.60 \pm 0.18$ & $1.72 \pm 0.25$ & $0.90 \pm 0.06$ & $1.23 \pm 0.09$ & $0.85 \pm 0.27$ & $1.21 \pm 0.21$ & $1.00 \pm 0.00$ & $1.10 \pm 0.10$ \\
\hline FMLP $10^{-8} \mathrm{M}$ & $\mathrm{N}$ & $3.55 \pm 0.32 \dashv$ & $3.72 \pm 0.19$ & $4.50 \pm 0.15$ & $4.08 \pm 0.17$ & $3.15 \pm 0.45$ & $5.14 \pm 0.14$ & $3.60 \pm 0.13$ * & $6.30 \pm 0.10$ \\
\hline FMLP $10^{-8} \mathrm{M}$ & $\mathrm{P}$ & $1.00 \pm 0.30$ & $5.56 \pm 0.70$ & $3.80 \pm 0.09$ & $4.15 \pm 0.07$ & $2.77 \pm 0.46$ & $5.43 \pm 0.14$ & $2.47 \pm 0.20^{*}$ & $5.40 \pm 0.20^{*}$ \\
\hline $\begin{array}{l}\text { LPS 活性化 } \\
\text { ヒト血清 }\end{array}$ & $\mathrm{N}$ & N.D. & $3.56 \pm 0.10_{\rceil}$ & $4.60 \pm 0.68$ & $3.38 \pm 0.08$ & $3.77 \pm 0.10$ & $4.07 \pm 0.00$ & $3.40 \pm 0.207$ & $6.30 \pm 0.20\rceil$ \\
\hline $\begin{array}{l}\text { LPS 活性化 } \\
\text { ヒト血清 }\end{array}$ & $\mathrm{P}$ & N.D. & $6.17 \pm 0.18^{-}$ & $4.40 \pm 0.07$ & $3.54 \pm 0.23$ & $3.53 \pm 0.30$ & $4.14 \pm 0.07$ & $2.87 \pm 0.13^{ل}$ & $4.40 \pm 0.20^{1}$ \\
\hline
\end{tabular}

き患者および健常者の, 同じ走化性因子に対する刺激指数の間に $\mathrm{P}<0.05$ (Student's $\mathrm{t}$ 検定)で有意差のあるもの

1） N：健常者末梢血より分離した単球

2） P：患者末梢血より分離した単球

例 2) および低下（症例 1) が各々 1 例ずつ認められ，限 局型 4 例中 2 例（症例 7,8 ）に有意の遊走能の低下が認 められた。

さらに，末梢血好中球および単球の遊走能異常に対す る歯周治療の影響を調べる目的で，歯周治療の終了した

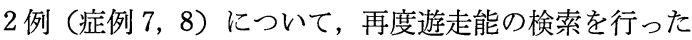
（表 3 ，表 4)。2 症例とも，末梢血好中球の遊走能は歯周 治療終了後もやはり有意の低下が認められ $(\mathrm{p}<0.05$, 表 3)，また末梢血単球の遊走能についても有意の低下が認 められた $(\mathrm{p}<0.05$, 表 4$)$ 。すなわち, 歯周治療を実施し た後でも, 末梢血好中球および単球の遊走能は健常者に 比べ低下したままであった。

\section{考察}

本研究で, 8 名の若年型重度歯周炎患者の未梢血白血 球の遊走能を健常者のものと比較した結果, 好中球の遊 走能低下は限局型 4 例中 2 例に観察され, 限局型では 50 \%の出現頻度であった。しかしながら，広汎型では 4 例 全てに好中球の遊走能低下は認められず, 逆に 1 例に遊 走能の亢進が観察された。また，この遊走能の亢進は， 限局型でも 1 例に認められた。LJP 患者における末梢血 好中球の遊走能低下の出現頻度に関する過去の報告をみ ると, Cianciola $ら^{13)}$ は 9 例中 9 例, Clark ら ${ }^{14)}$ は 9 例中 7 例, Lavine $ら^{15)}$ は 17 例中 12 例, Van Dyke $ら^{16)}$ は 32 
表 3 菌周治療終了後に抢ける末梢血好中球の 遊走能

\begin{tabular}{|c|c|c|c|}
\hline \multirow[b]{2}{*}{ 走化性因子 } & \multirow[b]{2}{*}{ 細胞 } & \multicolumn{2}{|c|}{ 刺激指数（平均 \pm S.E.） } \\
\hline & & $\begin{array}{l}\text { 症例 } 7 \\
(23 \text { 歳早) }\end{array}$ & $\begin{array}{l}\text { 症例 } 8 \\
(18 \text { 歳古) }\end{array}$ \\
\hline 無添加 & $\mathrm{N}$ & $1.00 \pm 0.11$ & $1.00 \pm 0.05$ \\
\hline 無添加 & $\mathrm{P}$ & $0.89 \pm 0.11$ & $0.95 \pm 0.11$ \\
\hline FMLP $10^{-6} \mathrm{M}$ & $\mathrm{N}$ & $6.37 \pm 0.26$ & $5.89 \pm 0.11 \neg$ \\
\hline FMLP $10^{-6} \mathrm{M}$ & $\mathrm{P}$ & $3.79 \pm 0.37-{ }^{*}$ & $5.00 \pm 0.11^{-1}$ \\
\hline $\begin{array}{l}\text { LPS 活性化 } \\
\text { 七ト血清 }\end{array}$ & $\mathrm{N}$ & $9.53 \pm 0.26\rceil$ & $6.89 \pm 0.16-$ \\
\hline $\begin{array}{l}\text { LPS 活性化 } \\
\text { ヒト血清 }\end{array}$ & $\mathrm{P}$ & $6.32 \pm 0.21\lrcorner$ & $7.21 \pm 0.32$ \\
\hline \multicolumn{4}{|c|}{ 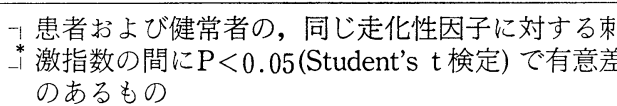 } \\
\hline \multicolumn{4}{|c|}{ 1） N：健常者末梢血より分離した好中球 } \\
\hline
\end{tabular}

例中 26 例, さらに Van Dyke ら ${ }^{17)} 26$ 例中 17 例とい う数值を報告している。これらの数值をまとめて，Van Dyke らはその総説 ${ }^{27)}$ の中で， $75 \%$ という出現頻度で LJP 患者に好中球の遊走能低下が認められると述べて いる。一方, GJP 患者における末梢血好中球の遊走能低 下の出現頻度については, Van Dyke らは 1980 年に 8 例 中 5 例 ${ }^{16)}$, さらに 1982 年の報告17) では 9 例中 4 例で, 両 方を加えて 17 例中 9 例 $(53 \%)$ といら数值を報告してい る17)。また Suzuki ら ${ }^{18)}$ も，GJP 患者において 24 例中 14 例 (58\%) という頻度で末梢血好中球の遊走能低下が 出現したことを報告している。このように，いずれの報 告でも, GJP 患者に扔ける末梢血好中球の遊走能低下の 出現頻度は, LJP 患者よりも低かった。

上記のアメリカでの研究に比べて, 本研究での末梢血 好中球の遊走能低下の出現頻度は低かった。この遊走能 低下の出現頻度が異なっている理由については, 我国に おける若年性歯周炎の研究報告, 特に白血球の遊走能に 関する報告がほとんどないため, 明確な結論を得ること ができないが，次のようなことが考えられる。まず，人 種差あるいは遺伝的要因の違いが考えられる。すなわ ち，アメリカに㧍ける報告をみると年 16,18)，LJP 患者は 白人に比べ黒人の症例が多い。また, 若年性歯周炎患者 の好中球の遊走能低下は, 歯周治療の有無関係なく認 められたという報告 ${ }^{14}{ }^{16)}$, さらに患者の兄弟で, 歯周組 織に異常が認められない臨床的健康者にも好中球の遊走 能低下が認められたこと帛より，この好中球の遊走能低 下は遺伝的素因に基づく機能不全であることが示唆され
表 4 歯周治療終了後に打ける末梢血単球の 遊走能

\begin{tabular}{|c|c|c|c|}
\hline \multirow[b]{2}{*}{ 走化性因子 } & \multirow[b]{2}{*}{ 細胞 } & \multicolumn{2}{|c|}{ 刺激指数（平均 \pm S.E. ) } \\
\hline & & $\begin{array}{l}\text { 症例 } 7 \\
(23 \text { 歳早) }\end{array}$ & $\begin{array}{l}\text { 症例 } 8 \\
\text { (18歳早) }\end{array}$ \\
\hline 無添加 & $\mathrm{N}$ & $1.00 \pm 0.00$ & $1.00 \pm 0.23$ \\
\hline 無添加 & $\mathrm{P}$ & $0.92 \pm 0.08$ & $1.00 \pm 0.00$ \\
\hline FMLP $10^{-8} \mathrm{M}$ & $\mathrm{N}$ & $5.75 \pm 0.25 \neg$ & $6.00 \pm 0.31 \neg$ \\
\hline $\mathrm{FMLP} 10^{-8} \mathrm{M}$ & $\mathrm{P}$ & $4.33 \pm 0.08^{*}$ & $4.08 \pm 0.23^{*}$ \\
\hline $\begin{array}{l}\text { LPS 活性化 } \\
\text { 七ト血清 }\end{array}$ & $\mathrm{N}$ & $5.33 \pm 0.25\rceil$ & $4.77 \pm 0.087$ \\
\hline $\begin{array}{l}\text { LPS 活性化 } \\
\text { 七ト血清 }\end{array}$ & $\mathrm{P}$ & لـ $4.00 \pm 0.08$ & لـ $4.15 \pm 0.08$ \\
\hline
\end{tabular}

ᄀ患者および健常者の，同じ走化性因子に対する刺

$\stackrel{*}{*}$ 激指数の間に $\mathrm{P}<0.05$ (Student's $\mathrm{t}$ 検定) で有意差 のあるもの

1） $\mathrm{N}$ ：健常者末梢血より分離した単球

2） P：患者末梢血より分離した単球

ている。したがって, 本研究と過去の報告との間にみら れる出現頻度の違いにも彼我の人種差あるいは遺伝的素 因の相違が影響している可能性が考えられる。しかしな がら, 本研究は過去の報告に比べると, 検索症例数が 8 例（限局型 4 例, 広汎型 4 例）と非常に少ないため, 遊 走能の低下を検出する確率が低くなった可能性も考えら れるため, この点に関して結論を出すにはさらに多数例 の検索が必要であろう。

次に, 出現頻度の相違をもたらす原因として, 遊走能 低下を発現させるような外因性あるいは環境因子が異な っている可能性が考えられる。すなわち, 欧米における 研究で LJP 患者の病変部ポケットから高率に検出され ている Actinobacillus actinomycetemcomitans のある株 は白血球毒性を有することが報告されている Okuda $~^{30)}$ は日本人の LJP 患者の歯周ポケット細菌叢 を調べた結果, A. actinomycetemcomitans の検出率が非 常に低かったことを報告しており, 彼我のポケット内細 菌叢が異なっている可能性を示唆している。したがっ て, この局所細菌叢の相違が遊走能低下の出現頻度の違 いに関与している可能性も考えられる。しかし,この点 に関して結論を得るためには, さらに多数例の若年性歯 周炎患者について, ポケット内細菌叢の解析を行う必要 がある。

さて, 本研究で広沉型 1 例, 限局型 1 例に認められた 好中球の遊走能立進は, Van Dyke ら $^{16)}$ の報告を見ても, GJP および LJP 患者群の両方にやはり好中球の遊走能 六進を示す患者が存在しており，この報告とも矛盾する 
ものではない。このように, 大半が好中球遊走能の低下 を示す若年性歯周炎患者の中に遊走能の穴進を示す患者 が存在する事実は，あるいは若年性歯周炎患者の病因・ 病態の多様性を示唆する一つの現象かも知れない。一 方, Van Dyke ${ }^{16)}$ は, 成人性歯周炎患者において, 遊 走能の有意の充進を示す者が健常者に比べて有意に増加 していたことを報告しており，この現象は細菌感染に反 応して好中球严集団内で遊走しやすい細胞群が増加する ことに生じるのではないかと推測している。

好中球遊走能の低下の発現機構としては, 液性因子に よる好中球の遊走障害と細胞性遊走障害の 2 通りが考え られている。液性因子としては, 走化性因子阻害因子 (chemotactic factor inactivator : CFI) と白血球に対す る直接阻害因子 (cell-direted inhibitor : CDI) が知られ ている。LJP 患者において, Clark ら ${ }^{14)}$ は 9 例中 5 例の 患者血清に CDI の存在を, Lavine ら ${ }^{15)}$ は 14 例中 3 例に CDI あるいは CFI の存在を, さらに Genco ら ${ }^{28)}$ は 21 例中 4 例に CDI の存在を報告している。しかし, これ ら液性因子の出現頻度は, 好中球の遊走能低下の出現頻 度ほどには高くなく, LJP 患者の好中球の遊走能低下に これらの液性因子の関与する確率は低いものと推察され る。

好中球に細胞性遊走障害が生ずる原因としては, 走化 性因子に対する認識障害 (レセプター障害), ランダム 運動の障害, 細胞変形能の障害などが考えられている。 LJP 患者では, ランダム運動とケモキネシスは正常であ り ${ }^{17)}$, さらに変形能にも異常が認められないこと28)より, 細胞の運動機能自体には異常がないと考えられている。 一方, LJP 患者の末梢血好中球では FMLP ${ }^{31)}$ や $\mathrm{C}^{3} \mathrm{a}^{32)}$ などの走化性因子に対するレセプター数が減少している ことが報告されており，このレセプター数の減少に基づ く走化性 (chemotaxis) の障害と考えられている。さて, 好中球には遊走する細胞群と, 遊走しない非遊走性細胞 群の 2 群が存在することが知られている ${ }^{33)}$ 。そして, Van Dyke ら ${ }^{17)}$ は, LJP 患者の末梢血好中球の遊走能の 低下は, 非遊走性の細胞群の増加によるものではなく, 遊走する細胞群の遊走が遅延することにより生じること を示唆した。

若年性歯周炎患者における好中球の遊走能低下は, 歯 周治療後の検查でも正常に回復しなかったことをVan Dyke $~^{16)}$, Clark ら ${ }^{14)}$ が報告している。本研究におい ても, 歯周治療開始時に好中球の遊走能低下が認められ た限局型 2 例（症例 7,8）について, 歯周治療終了後に 再度検索を行ったところ，2例とも遊走能の低下は依然
として認められた（表 3)。この結果は, Van Dyke ら ${ }^{16)}$, Clark ら ${ }^{14)}$ の報告と一致するものであり, これらの患者 における好中球の遊走能低下は一時的なものではなく, 患者の好中球に本質的な欠陥があることを示唆された。 Genco ら ${ }^{28)}$ は, LJP 患者の兄弟で, 歯周組織が健康な者 にも好中球の遊走能低下が存在したと報告しており, GJP 患者についても Vandesteen ら ${ }^{34)}$ が同様の報告を 行っている。これらのことより, この遊走能の低下の発 現には, 遺伝的素因が関与していると推測される。

本研究に括いては, 単球の遊走能低下が, 広沉型で 4 例中 1 例に, 限局型で 4 例中 2 例に認められ, さらに遊 走能の克進が広沉型 1 例に認められた (表 2)。若年性歯 周炎患者における単球遊走能に関する過去の報告では, 遊走能低下の出現頻度は好中球の場合よりも低いようで ある。すなわち, Cianciola ら ${ }^{13)}$ は LJP 患者 9 例におけ る検索で単球遊走能は正常であったと報告している。さ らに, Genco ら ${ }^{28)}$ は, 好中球の遊走能の低下のあった LJP 患者 7 例中 1 例に同時に単球の遊走能低下 が 認め られたと報告している。さらに, Suzuki ら ${ }^{18)}$ は LJP 患 者で 29 例中 1 例, GJP 患者で 24 例中 1 例に, 単球の遊 走能の低下が認められたことを報告している。いずれの 報告も, 本研究に打ける出現頻度 (8 例中 3 例, 広沉型 で 4 例中 1 例, 限局型で 4 例中 2 例) に比べれば低い傾 向を示している。彼我の間に, このような相違を生じた 理由としては, 好中球の場合と同じ 2 点が考えられる。 すなわち，第一の理由は，人種差あるいは遺伝的素因の 違いである。なぜならば, 本研究で認められた単球の遊 走能低下は歯周治療後の検査でも存在しており（表 4), また別論文 ${ }^{35)}$ で報告するように家族性に単球の遊走能低 下が出現している場合もあり, 好中球の場合と同様に, 遺伝的素因が関与していると推測されるからである。さ らに, 本研究で 2 名の限局型患者に好中球と単球の遊走 能低下が同時に認められたことも，遺伝的素因の関与を 示唆するものであるかも知れない。第 2 の理由として, 好中球の場合と同様に, 遊走能低下をもたらす外来性因 子の違いが関与している可能性も考えられる。しかしな がら, この単球遊走能の低下の出現頻度の相違について の結論を得るためには, やはりさらに多数例の検索が必 要と考えている。

単球遊走能の低下が何に起因するかは, 現在まったく 不明であり,またこの単球遊走能の低下の若年性歯周炎 の病因論における意義は, 好中球の場合ほど明確にされ ていない。しかし, Liljenberg ら ${ }^{36)}$ は, 若年性歯周炎患 種の病変部歯肉結合組織中にみられる浸潤細胞中に, 単 
球一マクロファージが占める割合は $0 \sim 0.05 \%$ と, 成人 型歯周炎の場合（4\%）に比べて低いことを報告してお り, この報告はin vivo において単球遊走能の低下が生 ビていることを示唆するものであるかも知れない。

\section{結論}

18 26 歳の重度歯周炎患者 8 名 (広沉型 4 例, 限局型 4 例）を対象として, 末梢血好中球および単球の遊走能 の検荣を行い, 歯周組織に異常を認めない健常者と比較 することにより，以下の所見を得た。

1. 患者末梢血好中球の遊走能については, 広汎型で は 4 例中 1 例に六進が認められる他は遊走能異常が認め られなかったが，限局型では 4 例中 2 例に有意の低下， 1 例に有意の六進が認められた。限局型における好中球 の遊走能低下の出現頻度は $50 \%$ であった。

2. 患者末梢血単球の遊走能は, 広汎型では 4 例中 1 例に有意の京進, さらに 1 例に有意の低下が認められ た。限局型では 4 例中 2 例に有意の低下が認められた が, この単球遊走能の低下を示した限局型 2 例は, 好中 球の遊走能においても低下を示した症例であった。

3. 歯周治療前に, 好中球および単球の遊走能の低下 が認められた限局型 2 例について, 歯周治療終了後に再 度遊走能の検索を実施した結果, 好中球および単球の遊 走能の低下は依然として認められ，これらの遊走能低下 は患者の生来保有している素因であることが示唆され た。

本研究費の一部は, 1984 年 (昭和 59 年度) および 1985 年 (昭 和 60 年度) の文部省科学研究費総合研究 $\mathrm{A}$ 「若年者における重 度進行性の歯周疾患の病理病態解析」の援助を受けた。記して 謝したい。

\section{引用文献}

1) Page, R.C. and Schroeder, H.E. : Pathogenesis of inflammatory periodontal disease. A summary of current works. J. Lab. Invest., 33 : 235249, 1976.

2) Attström, R. : Presence of leukocytes in crevice of healthy and inflamed gingivae. J. Periodont. Res., 5 : 42-47, 1970.

3) Attström, R. : The role of gingival epithelium and phagocytosing leukocytes in gingival diff- ence. J. Clin. Periodontol., 2 : 25-32, 1975.

4) Attström, R. and Schroeder, H.E. : Effect of experimental neutropenia on initial gingivitis in dogs. Scand. J. Dent. Res., $87:$ 7-23, 1979.

5) Hellden, L. and Lindhe, J. : Enhanced emigration of crevicular leukocytes mediated by factors in human dental plaque. Scand. J. Dent. Res., 81 : 123-129, 1973.

6) Tempel, T.R., Snyderman, R., Jordan, H.V. and Mergenhergen, S.E. : Factors from saliva and oral bacterial chemotactic for polymorphonuclear leukocytes: their possible role in gingival inflammation. J. periodontol., $41: 71-80$, 1970.

7) Tempel, T.R., Kimball, H.R., Kakehashi, S. and Amen, C.R. : Host factors in periodontal manifestrations in Chédiak-Higashi syndrome. J. Periodont. Res., 7 (suppl. 10) : 26-27, 1972.

8) Picunus, S.H., Thomas, I.T., Clark, R.A. and Ochs, H.S. : Defective neutrophil chemotaxis with variant icthyosis, hyperimmunoglobulinemia $\mathrm{E}$ and recurrent infections. J. Pediatr., 87 : 908-911, 1975.

9) Cohen, D.W. and Morris, A.L. : Periodontal manifestration of cyclic neutropenia. J. Periodont. Res., 32 : 159-168, 1961.

10) Miller, M.E., Oski, F.A. and Harris, M.B. : Lazy leukocyte syndrome: a new disorder of neutrophil function. Lancet, 1 : 665-669, 1971.

11) Hill, H.R., Sauls, H.S., Dettloff, J.L. and Quie, P.G. : Impaired leukotactic responsiveness in patient with juvenile diabetes mellitus. Clin. Immunol. Immunopathol., $2:$ 395-403, 1974.

12) Mowat, A.G. and Baum, J. : Chemotaxis of polymorphonuclear leukocytes from patients with diabetes mellitus. N. Eng. J. Med., 284 : 621-627, 1971.

13) Cianciola, L.J., Genco, R.J., Patters, M.R., McKenna, J. and Van Oss, C.J. : Defective polymorphonuclear leukocyte function in human periodontal disease. Nature, $265: 445-447$, 1977.

14) Clark, R.A., Page, R.C. and Wilde, G. : Defective neutrophil chemotaxis in juvenile perio- 
dontitis. Infect. Immun., 18 : 694-700, 1977.

15) Lavine, W.S., Moderazo, E.G., Stoleman, J., Ward, P.A., Cogen, R.B., Greenblatt, I. and Robertson, P.B. : Impaired neutrophil chemotaxis in patients with juvenile, rapidly progressing periodontitis. J. Periodont. Res., 14 : 1019, 1979.

16) Van Dyke, T.E., Horoszewicz, H.U., Cianciola, L.J. and Genco, R.J. : Neutrophil chemotaxis dysfunction in human periodontitis. Infect. Immun., 27 : 124-132, 1980.

17) Van Dyke, T.E., Horoszewicz, H.U. and Genco, R.J. : The polymorphonuclear leukocyte (PM $\mathrm{NL)}$ locomotor defect in juvenile periodontitis. Study of randon migration, chemokinesis and chemotaxis. J. Periodontol., 53 : 682-687, 1982.

18) Suzuki, J.B., Collison, B.C., Falkeler, Jr., W. A. and Nauman, R.K. : Immunologic profile of juvenile periodontitis. II. Neutrophil chemotaxis, phagocytosis and spore germination. J. Periodontol., 55 : 461-467, 1984.

19) Page, R.C., Altman, L.C., Ebersole, J.L., Vandesteen, G.E., Dahlberg, W.H., Williams, B.L. and Osterberg, S.K. : Rapidly progressive periodontitis : a distinct clinical condition. J. periodontol., 54 : 197-209, 1983.

20）岡田 宏, 島内英俊, 葛西康宏, 木田友信, 恵比 須繁之：若年層にみられる重度歯周炎の病理病態 解析 I. 臨床所見と血液所見ならびに免疫病理 学的検討. 日歯周誌, $28: 307-317,1986$.

21) Böyum, A. : Isolation of mononuclear cells and granulocytes from human blood. Scand. J. Clin. Lab. Invest., 21 (Suppl. 97) : 77-89, 1968.

22) Snyderman, R., Altman, L.C., Hausman, M.S. and Mergenhergen, S.E. : Human mononuclear leukocyte chemotaxis: A quantitative assay for humoral and cellular chemotactic factor. J. Immunol., $108:$ 857-860, 1972.

23) Shiffman, E., Corcoran, B.A. and Wahl, S.M. : $N$-formylmethionyl peptides as chemotactic attractants for leukocytes. Proc. Nat. Acad. Sci. USA, 72 : 1059-1062, 1975.

24) Snyderman, R. and Pike, M.C. : Methodology in leukocyte chemotaxis : methods, physiology and clinical implications (Gallin, J.I. and Quite, P.G. editor). Raven Press, New York, 1978, 73-78.

25) Falk, W., Goodwin, Jr., R.H. and Leonard, E.J. : A 48-well micro chemotaxis assembly for rapid and accurate measurement of leukocyte migration. J. Immunol. Methods, 33 : 239-247, 1980.

26) Harvarth, L., Falk, W. and Leonard, E.J. : Rapid quantitation of neutrophil chemotaxis : Use of a polyvinylpyrrolidone-free polycarbonate menbrane in a multiwell assembly. J. Immunol. Methods, 37 : 39-45, 1980.

27) Van Dyke, T.E., Levine, M.E. and Genco, R. J. : Neutrophil function and oral disease. J. Oral Pathol., 14 : 95-120, 1985.

28) Genco, R.J., Van Dyke, T.E., Park, B., Ciminelli, M. and Horoszewicz, H. : Neutrophil chemotaxis impairment in juvenile periodontitis : Evaluation of specificity, adherence, deformability and serum factors. J. Reticuloendothel. Soc., 28 (Suppl.) : 815-819, 1980.

29) Baehni, P., Tsai, C.C., McArthur, W.P., Hammond, B.F. and Taichman, B.F. : Interaction of inflammatory cells and microorganisms. VIII. Detection of leukotoxic activity of plaquederived microorganisms. Infect. Immun., 24 : 233-243, 1979.

30) Okuda, K. Naito, Y., Ohta, K., Fukumoto, Y., Kimura, Y., Ishikawa, I., Kinoshita, S. and Takazoe, I. : Bacteriological study of periodontal lesion in two sisters with juvenile periodontitis and their mother. Infect. Immun., 45 : 118-121, 1985.

31) Van Dyke, T.E., Levine, M.J., Tabak, L.A. and Genco, R.J. : Reduced chemotactic peptide binding in juvenile periodontitis. Biochem. Biophys. Res. Comm., 100 : 1278-1284, 1981.

32) Van Dyke, T.E., Levine, M.J., Tabak, L.A. and Genco, R.J. : Juvenile periodontitis as a model for neutrophil function : reduced binding of complement chemotactic fragment C5a. J. Dent. Res., $62: 870-872,1983$.

33) Harvarth, L. and Leonard, E.J. : Two neutro- 
phil population in human blood with different chemotactic activities : separation and chemoattractant binding. Infect. Immun., $36: 443-$ 449, 1982.

34) Vandesteen, G.E., Altman, L.C. and Page, R. C. : Peripheral blood abnormalities and periodontal disease : A family study. J. Periodontol., 52 : 174-180, 1981.
35）恵比須繁之, 島内英俊, 葛西康宏, 脇田由美子, 鮫島義明, 神山 章, 福原弘喜, 岡田 宏 : 家族 性にみられた若年性歯周炎の病態解析, 日歯周誌, $28: 327-338,1986$.

36) Liljenberg, B. and Lindhe, J. : Juvenile periodontitis: Some microbiological, histopathological and clinical characteristics. J. Clin. Periodontol., $7:$ 48-61, 1980. 